\title{
Blastocysts exhibit sex-specific signalling of IFNT transcription, translation and activity
}

\author{
Corina I Schanzenbach ${ }^{1}$, Sandra M Bernal-Ulloa ${ }^{1}$, Vera A van der Weijden¹, Michael W Pfaffl'², \\ Mathias Büttner ${ }^{3, \dagger}$, Annegret Wünsch ${ }^{4}$ and Susanne E Ulbrich ${ }^{1}$ \\ ${ }^{1}$ Department of Environmental Systems Science, Animal Physiology, Institute of Agricultural Science, ETH Zürich, \\ Zurich, Switzerland, ${ }^{2}$ Department of Animal Sciences, Animal Physiology and Immunology, Wissenschaftszentrum \\ Weihenstephan, Technische Universität München, Freising, Germany, ${ }^{3}$ Bavarian Health and Food Safety Authority, \\ Oberschleissheim, Germany and ${ }^{4}$ Ludwig-Maximilians-Universität München, Chair for Molecular Animal Breeding \\ and Biotechnology, Munich, Germany
}

Correspondence should be addressed to S E Ulbrich; Email: susanne.ulbrich@usys.ethz.ch

${ }^{+}$(M Büttner is now at Institute of Immunology, Veterinary College BBZ, University of Leipzig, Leipzig, Germany)

\begin{abstract}
Preimplantation bovine blastocyst supernatants exhibit sex-dependent antiviral activity, due to the ruminant pregnancy recognition signal interferon tau (IFNT). Differing potencies of IFNT variants have been supposed as cause, although evidence remains scarce. Here, we aimed at quantifying the sex-dependent IFNT production on transcriptional, translational and biological activity level in bovine blastocysts, to elucidate the origin of differences in antiviral activity between male and female blastocysts. Day 8 bovine blastocysts were co-cultured with endometrial stroma cells for $48 \mathrm{~h}$. The embryonic IFNT mRNA expression was determined by quantitative reverse transcription followed by polymerase chain reaction (RT-qPCR). Additionally, the IFNT protein concentration was determined using a sensitive in-house developed IFNT-specific enzyme-linked immunosorbent assay (ELISA). The biological activity was assessed by quantifying the response of interferon-stimulated gene (ISG) expression in endometrial stroma cells. While the IFNT-specific ELISA displayed a limit of detection of $7.3 \mathrm{pg} / \mathrm{mL}$, the stroma cell culture system showed to react to as little as $0.1 \mathrm{pg} / \mathrm{mL}$ IFNT in RT-qPCR analysis. The female blastocysts had a significant, 5.6-fold, 3.6-fold and 5.2-fold higher IFNT production than male blastocysts as determined by transcript abundance, protein concentration and, protein activity, respectively. Additionally, all parameters correlated positively, and therefore, we conclude that female blastocysts most likely have an increased IFNT gene and protein expression rather than expressing more potent IFNT variants.

Reproduction (2019) 157 245-258
\end{abstract}

\section{Introduction}

The most important pregnancy recognition signal known in ruminants is the cytokine interferon tau (IFNT). Its major role is the maintenance of pregnancy by rescuing the corpus luteum $(\mathrm{CL})$. IFNT diverged from its closest relative IFN omega some 36 million years ago and belongs to the type 1 interferons (Michael Roberts et al. 1997, Brooks \& Spencer 2015). The intronless gene is encoded several times in a cluster region of the bovine genome (Leaman \& Roberts 1992, Leaman et al. 1994). Currently, 29 different IFNT sequences for cattle are deposited in the GeneBank database that differ in single nucleotides. The protein is restricted to the ruminant species, where expression is limited to the trophectoderm of the developing embryo (Farin et al. 1989). While only minute amounts are secreted at the time of blastocyst formation, increasing amounts are present in the uterine fluid during elongation of the trophoblast. With the start of implantation, the concentration decreases and soon vanishes (Farin et al. 1990, Hernandez-Ledezma et al. 1992, Ealy et al. 2001).

Even though IFNT has several unique features, it shares many structural characteristics with the other members of group 1 interferons. Specifically, cell signalling pathways are induced via interferon-alpha/beta receptor subunit 1 and 2 (IFNAR1 and IFNAR2) receptor binding. The classical receptor binding in uterine stroma and glandular epithelia cells leads to the activation of the JAK/STAT signalling pathway-related expression of GASregulated genes like interferon regulatory factor 1 (IRF1). The latter is responsible for the activation of interferonstimulated response elements, and thus, expression of many classical Interferon-stimulated genes (ISG) like 2'-5'-oligoadenylate synthetase 1 (OAS1), interferonstimulated gene 15 (ISG 15) or MX dynamin-like GTPase 2 (MX2) (Choi et al. 2001, Hansen et al. 2017). All three classical ISGs are involved in immune modulation 
and antiviral response (Sadler \& Williams 2008). In this way, the target effect signalling of IFN is strongly amplified. In the ovine uterine luminal and superficial glandular epithelia, IRF2 is inhibiting the classical JAK/ STAT signalling. Consequently, alternative cell signalling pathways are activated (Choi et al. 2001, Bazer et al. 2008). This leads to transcriptional silencing of oestrogen receptor alpha (ESR1) and oxytocin receptor (OXTR) and thus the prevention of luteolysis (Spencer \& Bazer 1996, Bazer et al. 2015).

Different methods for IFNT quantification are available at present. Gene transcription can be determined from the 16-cell stage (day 4) onwards in IVF embryos (Yao et al. 2009). For protein quantification, several radioimmunoassays (RIAs) have been reported with sensitivities ranging from $6 \mathrm{ng} / \mathrm{mL}$ (Takahashi et al. 2005) to $39 \mathrm{pg} / \mathrm{mL}$ (Romero et al. 2015). Furthermore, it is well accepted that interferons have antiviral activity. Therefore, at the level of protein activity, an antiviral activity assay is frequently used. The protein concentration or activity unit protecting $50 \%$ of Madin-Darby bovine kidney (MDBK) cells after a challenge with vesicular stomatitis virus is determined (Rubinstein et al. 1981, HernandezLedezma et al. 1993). A sensitivity of $0.1 \mathrm{IU}$ has been reported for this assay (Hernandez-Ledezma et al. 1992, 1993). However, this assay has the disadvantage of using a viable virus and it cannot appropriately distinguish IFNT from other type 1 interferons. Therefore, alternative cell-based assays using reporter genes have been developed in MDBK cells with reported sensitivities of $0.25 \mathrm{IU} / \mathrm{mL}$ IFN alpha (IFNA) (Fray et al. 2001), $0.5 \mathrm{IU} / \mathrm{mL}$ IFNA (McCoski et al. 2014) and $400 \mathrm{pg} / \mathrm{mL}$ equalling approximately $8 \mathrm{IU} / \mathrm{mL}$ IFNT (Toji et al. 2018). Furthermore, the induction of ISG quantified on the level of gene transcription in cells expressing IFNAR has likewise been approved as an indirect method to quantify the presence of IFNT (Spencer et al. 1999, Matsuyama et al. 2012, Kim et al. 2013).

A sexual dimorphism in IFNT production in bovine blastocysts has been documented at the level of antiviral activity in both in vivo- and in vitro-derived blastocysts (Larson et al. 2001, Kimura et al. 2004a). In detail, a 1.8- and 4.3-fold higher antiviral activity has been shown in supernatants of female compared to male in vitro-derived day 8 blastocysts (Larson et al. 2001) and in in vivo-derived day 8.5-9.5 blastocysts after $24 \mathrm{~h}$ of culture (Kimura et al. 2004a), respectively. However, this difference disappeared during further development on day 14 (Kimura et al. 2004a) and on day 16 (Forde et al. 2016) after fertilization. While the cause of the difference is still unclear, there is high evidence that nutritional energy intake for males is higher and that the increased IFNT production in females could consequently compensate for this deficit by signalling their presence more robustly (Larson et al. 2001, Kubisch et al. 2003, Kimura et al. 2004b). The fact that the sexual dimorphism is only present from day 8 until approximately day 14 after fertilization further suggests a direct linkage to $\mathrm{X}$-chromosome inactivation, which takes place in female bovine embryos during that time (Kimura et al. 2004a, Bermejo-Alvarez et al. 2011).

While antiviral activity has been shown to be sex dependent in bovine blastocysts, knowledge on IFNT mRNA or protein expression differences between sexes is scarce. Walker et al. 2009 explicitly investigated sexdependent mRNA expression level at the blastocyst stage (day 8) including the differential expression of IFNT variants aiming at elucidating their responsibility for the diverse antiviral activity between sexes. However, the authors could neither show expression differences of the IFNT variants, nor for total IFNT mRNA expression. Thus, an explanation for the link between IFNT mRNA expression and activity is missing to date.

In this study, we aimed at quantifying the sexdependent IFNT production on transcriptional and a translational level. For the latter, we developed a sensitive IFNT ELISA. We additionally aimed at assessing the biological activity of IFNT by validating an embryo-stroma cell co-culture approach to detect minute amounts of native IFNT. We then determined the correlation between the three different measures used for IFNT quantification to elucidate the cause of differences in antiviral activity between male and female preimplantation blastocysts.

\section{Materials and methods}

All media or buffers were in-house prepared according to the manufacturer's recommendations. All reagents of analytical grade were supplied by Sigma-Aldrich Co., while columns, concentrators and kits for protein chemistry were purchased by Thermo Fisher Scientific unless stated otherwise.

\section{In vitro embryo production}

\section{In vitro oocyte maturation (IVM)}

Bovine oocytes were retrieved by slicing ovaries, which were collected from a local slaughterhouse and transported to the lab at $30-35^{\circ} \mathrm{C}$. Ovary slicing, oocyte collection, maintenance and selection were performed at $35^{\circ} \mathrm{C}$ in TCM199, supplemented with $50 \mu \mathrm{g} / \mathrm{mL}$ gentamicin sulphate, $0.2 \mathrm{mM}$ Na-pyruvate, $4.2 \mathrm{mM} \mathrm{NaHCO}$ and $1 \mathrm{mg} / \mathrm{mL}$ BSA-FAF (TCM-air medium; Bernal-Ulloa et al. 2016a). Oocytes were classified according to cytoplasm characteristics and number of cumulus cell layers. Only category I (light or transparent cumulus oophorous with more than four layers of compact and a clear and even cytoplasm) and category II oocytes (compact cumulus oophorous with less than four layers and/or cytoplasm usually homogenous but with a coarser appearance) were selected for in vitro maturation (Looney et al. 1994, Goodhand et al. 1999). A standard in vitro maturation (IVM) was performed in low glucose DMEM medium due to good reported developmental rates and embryo quality (Vejlsted et al. 2005, Jensen et al. 2014, Valleh et al. 2015) containing $50 \mu \mathrm{g} / \mathrm{mL}$ gentamycin, 
$1 \mathrm{mg} / \mathrm{mL}$ BSA-FAF, $50 \mathrm{ng} / \mathrm{mL}$ epidermal growth factor (EGF), $10 \mathrm{IU} / \mathrm{mL}$ of equine chorion gonadotropin (eCG) and 5IU/ $\mathrm{mL}$ of human chorionic gonadotropin (P.G.600, MSD Animal Health $\mathrm{GmbH}$, Luzern). Oocytes were incubated in groups of 20 in $500 \mu \mathrm{L}$ of medium in four-well dishes in a humidified atmosphere at $38.8^{\circ} \mathrm{C}$ and $6 \% \mathrm{CO}_{2}$ in air for $24 \mathrm{~h}$. A $6 \% \mathrm{CO}_{2}$ concentration has been adjusted to keep the desired $\mathrm{pH}$ in the medium for our in vitro embryo production system.

\section{In vitro oocyte fertilization (IVF) and in vitro embryo culture (IVC)}

Matured oocytes were washed in $3 \mathrm{~mL}$ of pre-equilibrated fertilization medium (Fert-TALP), supplemented with $6 \mathrm{mg}$ / $\mathrm{mL}$ BSA (fraction V), $0.05 \mathrm{mg} / \mathrm{mL}$ gentamicin and $0.028 \mathrm{mg} / \mathrm{mL}$ Na-pyruvate. For IVF, oocytes were transferred in $50-430 \mu \mathrm{L}$ in four-well dishes of Fert-TALP containing $10 \mu \mathrm{M}$ hypotaurine, $0.1 \mathrm{IU} / \mathrm{mL}$ heparin (AppliChem, Darmstadt, Germany) and $1 \mu \mathrm{M}$ epinephrine (Bernal et al. 2015). Two gradients of BoviPure (Nidacon International AB, Mölndal, Sweden) (40 and $80 \%$ ) were applied to isolate motile from non-motile spermatozoa from frozen/thawn commercial sperm straws. Only one bull with proven in vivo and in vitro history of fertility was used for IVF and embryo production. BoviPure gradients were prepared in conformity with the manufacturer's instructions. Spermatozoa were initially centrifuged at $400 \mathrm{~g}$ for $10 \mathrm{~min}$. Thereafter, sperm was washed once in Fert-TALP and centrifuged again at $400 \mathrm{~g}$ for $3 \mathrm{~min}$. A second wash in IVF medium and further centrifugation was performed as before. Motile spermatozoa were added to IVF wells at a final concentration of $2 \times 10^{6}$ cells $/ \mathrm{mL}$. Oocytes were co-incubated with the spermatozoa in groups of 20 for $19 \mathrm{~h}$, in a humidified atmosphere of $6 \% \mathrm{CO}_{2}$ in air at $38.8^{\circ} \mathrm{C}$. At the end of IVF, presumptive zygotes were subjected to vortexing for $2 \mathrm{~min}$ in TCM-air medium for sperm and cumulus cells removal. Subsequently, zygotes were washed in $3 \mathrm{~mL}$ pre-equilibrated SOF medium supplemented with $4 \mathrm{mg} / \mathrm{mL}$ of BSA-FAF (BernalUlloa et al. 2016b). In vitro embryo culture was performed in groups of 20 in $500 \mu \mathrm{L}$ SOF under silicone oil using four-well dishes. A humidified atmosphere at $38.8^{\circ} \mathrm{C}$ in $6 \% \mathrm{CO}_{2}, 6 \%$ $\mathrm{O}_{2}$ and balanced $\mathrm{N}_{2}$ was used. Embryo developmental rates (cleaved embryos or blastocysts/total cultured oocytes, with the oocytes as experimental units) were evaluated after $72 \mathrm{~h}$ and at day 8 for cleavage and blastocyst formation, respectively.

\section{ELISA establishment}

An IFNT ELISA was established in-house, including antigen expression, polyclonal antibody generation in rabbits and ELISA establishment and validation. The two IFNT variants 1c and $3 a$ were chosen with the aim to differentiate between the native proteins because they are considered to have most biological relevance (Walker et al. 2009). For IFNT cloning, expression and clean up, IFNT transcripts were amplified from bovine 18-day-old trophoblast cDNA by Fast Start High Fidelity PCR System (Roche). The PCR product including a HisTag was ligated into the vector pET28a and transformed into Escherichia coli (E. coli) transformation strain XL-1 blue. After identifying and sequencing the plasmids including the correct and desirable IFNT transcripts, the corresponding vectors were further transformed into the $E$. coli expression strain (Rosetta II). The obtained $E$. coli clones were then used for recombinant expression of the two IFNT variants IFNT 1C (Gene Bank ID: AAF08671.2) and IFNT 3a (Gene Bank ID: AF196324.1) for antigen production. The $E$. coli cells were cultivated in $1 \mathrm{~L} \mathrm{LB}$ medium $(10 \mathrm{~g} / \mathrm{L}$ peptone, $5 \mathrm{~g} / \mathrm{L}$ yeast extract, $5 \mathrm{~g} / \mathrm{L} \mathrm{NaCl}, \mathrm{pH}$ 7.2) (Carl Roth, Karlsruhe, Germany) containing $25 \mathrm{mg} / \mathrm{mL}$ kanamycin (Carl Roth) and $35 \mathrm{mg} / \mathrm{mL}$ chloramphenicol at $37^{\circ} \mathrm{C}$ until an $\mathrm{OD}_{600}$ of 1 was reached. The culture was then induced with $\quad 1 \mathrm{mM}$ isopropylthio-b-D-1-thiogalactopyranoside (IPTG) and expressed at $18^{\circ} \mathrm{C}$ overnight. IFNT was purified according to Klemann et al. (1990) as follows: bacteria were pelleted and washed with Tris-buffered saline (TBS) $(20 \mathrm{mM}$ Tris- $\mathrm{HCl}, 300 \mathrm{mM} \mathrm{NaCl}, \mathrm{pH}$ 8) (Merck). In order to access the expressed IFNT in inclusion bodies, the cell pellet was enzymatically lysed overnight with lysis buffer containing $1 \mathrm{mM}$ phenylmethanesulfonyl fluoride (PMSF) (Carl Roth) as protease inhibitor and $250 \mu \mathrm{g} / \mathrm{mL}$ lysozyme, and additional mechanical disruption by sonication for $10 \mathrm{~min}(5 \mathrm{~s}, 10 \mathrm{~s}$ pause) on ice. The disrupted cells were then ultracentrifuged for $25 \mathrm{~min}$ at $4^{\circ} \mathrm{C}$ and 150,000 $\mathrm{g}$ (Beckmann Coulter, SW28 Rotor). The supernatant was discarded and the inclusion body containing cell debris washed twice with TBS containing $1 \%$ Triton-X-100 (ICN Biomedicals, Irvine, USA), and twice with TBS only by resuspension and subsequent ultracentrifugation $\left(25 \mathrm{~min}\right.$ at $4^{\circ} \mathrm{C}$ and $150,000 \mathrm{~g}$ ). The protein was then refolded by dissolving it in TBS containing $6 \mathrm{M}$ guanidium hydrochloride (Schwarz/Mann Biotech, Orangeburg, USA) and $0.1 \%$ b-mercaptoethanol under shaking conditions at room temperature for up to $3 \mathrm{~h}$. Remaining large particles were removed by centrifugation at $3200 \mathrm{~g}$ for $20 \mathrm{~min}$ at $4{ }^{\circ} \mathrm{C}$. Afterwards, TBS buffer containing $0.1 \% \mathrm{~b}$-mercaptoethanol was slowly dropped to the dissolved proteins at $4{ }^{\circ} \mathrm{C}$. Thereafter, it was dialyzed in a $6-8 \mathrm{kDa}$ dialysing tube (Spectrum Laboratories, Irving, USA) at $4^{\circ} \mathrm{C}$ against $2 \times 1 \mathrm{LTBS}$ overnight. The content of the dialysis tube was then centrifuged $(10 \mathrm{~min}$, $3200 \mathrm{~g}, 4^{\circ} \mathrm{C}$ ). The liquid fraction holding the dissolved and refolded IFNT was further His-Tag purified using the HisPur Ni-NTA Spin columns. Afterwards the buffer was exchanged to remove imidazole (Merck) and the protein concentrated in a $10 \mathrm{~K}$ MWKO centrifugal concentrator. In order to use the IFNT protein for immunization and under cell culture conditions, endotoxins were removed using High-Capacity Endotoxin Removal Spin Columns. The protein concentration was quantified using a BCA protein assay, with BSA as a standard. The protein was further characterized using SDS-PAGE and mass spectrometry. The antiviral activity was determined using a bovine kidney cell line (MDBK) challenged with a vesicular stomatitis virus (Indiana strain) (Rubinstein et al. 1981). The $50 \%$ protection of the cells by a serial dilution of the recombinant IFNT was considered $1 \mathrm{IU} / \mathrm{mg}$ and compared to a human IFNA, reference preparation (No. Gxa01-901-535 NIH-Research Reference Reagent Note No. 31. 1984).

\section{Antibody generation and purification}

Animal experiments were performed in accordance to the German Animal Welfare regulations and had been approved by the local supervisory body (Regierung Oberbayern, Bavaria, 
Germany, animal approval number: 55.2-1-54-2532.6-4-12.). Polyclonal antibodies were generated in rabbits at the research station Veitshof in Weihenstephan, Germany, in accordance with the procedure described by Paul et al. (2008). Two rabbits were immunized with either IFNT 1c (females, 4 and 1 year old) or with IFNT 3a (males, 1 year old). For immunization, $300 \mu \mathrm{g}$ of antigen was mixed 1:1 with incomplete Freud'sch adjuvants and injected intradermal at approximately 25 injection sites. The boosting reactions were repeated every 3 weeks for four times, and subsequently every 6 weeks. A maximum of $10 \%$ of the whole blood volume of the animal, estimated by its weight, was taken from the ear veins the first time after 3 months of immunization and then every 3 weeks. The blood was collected in tubes containing EDTA and acetylsalicylic acid. Directly after collection, the blood was centrifuged $\left(2000 \mathrm{~g}, 15 \mathrm{~min}, 4^{\circ} \mathrm{C}\right)$, plasma recovered and stored at $-20^{\circ} \mathrm{C}$.

The specific anti-IFNT antibodies were purified using affinity purification according to Paul et al. 2008. For this, IFNT was covalently bound onto $\mathrm{CNBr}^{-}$activated sepharose and packed onto columns (GE Healthcare). Unspecific binding particles of the plasma were washed from the column using phosphatebuffered saline (PBS) $\left(1.8 \mathrm{mM} \mathrm{KH}_{2} \mathrm{PO}_{4}, 137 \mathrm{mM} \mathrm{NaCl}, 2.7 \mathrm{mM}\right.$ $\mathrm{KCl}, 8.1 \mathrm{mM} \mathrm{Na} \mathrm{HPO}_{4} \times 2 \mathrm{H}_{2} \mathrm{O}, \mathrm{pH} \quad 7.4$ ) (Merck), $0.5 \mathrm{M}$ $\mathrm{NaSCN}$ and glycin buffer $(0.1 \mathrm{M}$ glycin, $0.9 \% \mathrm{w} / \mathrm{v} \mathrm{NaCl})$ (Merck) adjusted to a $\mathrm{pH}$ of 3.5. The anti-IFNT antibodies were finally eluted using glycin buffer at $\mathrm{pH}$ 2.0. The eluted fractions were immediately neutralized with $1 \mathrm{M}$ Tris- $\mathrm{HCl}$ in order to maintain antibody stability, and shortly afterwards, the buffer was exchanged to PBS with a $100 \mathrm{~K}$ centrifugal MWCO concentrator, $\mathrm{pH} 7.4$.

For the sandwich ELISA set up, the antibody for specific antigen capture was aliquoted and frozen at $-20^{\circ} \mathrm{C}$. A second antibody for antigen-specific binding and a parallel detection was first biotinylated with the EZ-Link Sulfo-NHS-LC Biotinylation Kit before being aliquoted and frozen. All antibody concentrations were determined by a BCA assay with BSA as a standard.

\section{ELISA establishment and validation}

In total, antibodies of four animals were generated. All antibodies were analysed in a titre test and tested in a sandwich ELISA setup. In a crosswise analysis, the pair of antibodies resulting in the best sensitivity and lowest background was selected. A checkboard titration was used to determine the most sensitive antibody concentrations with the selected pair of antibodies. All buffer compositions, enzymes and incubation times were optimized in order to reach highest sensitivity for IFNT detection.

The IFNT ELISA was validated for the following parameters:

Sensitivity: Limit of detection $($ LOD $)=3 \times$ s.D. (0-value) + OD450 0-value; limit of quantification $(\mathrm{LOQ})=10 \times$ s.D. (0-value) + OD450 0-value; LOD and LOQ were calculated on four different days with $n=17-280$-values.

Specificity: Recovery (\%) of the closely related IFNA, interferons beta (IFNB), gamma (IFNG) (Kingfisher, Saint Paul, USA) and omega (IFNW) (Cusabio, College Park, USA) was analysed in the range of $1 \mathrm{pg} / \mathrm{mL}$ to $1 \mu \mathrm{g} / \mathrm{mL}$.
Intra-assay variation: Coefficient of variation (CV) (\%) of 500, 100, 25 and $10 \mathrm{pg} / \mathrm{mL}$; variation was calculated between eight samples on one plate measured on three different days.

Inter-assay variation: CV (\%) of 500, 100, 25 and $10 \mathrm{pg} / \mathrm{mL}$; variation was calculated between five different days.

Recovery rate: Recovery (\%) of 500, 100, 25 and $10 \mathrm{pg} / \mathrm{mL}$ spike-ins; recovery (\%) was calculated at five different days.

Linear dilution: Recovery rate after a 1:1 dilution of IFNT standard in assay buffer $(A B)$, synthetic oviductal fluid (SOF medium), uterine flushing and DMEM/F12 + 10\% foetal bovine serum (FBS).

Parallelism: Dilution rates of measured IFNT concentration after a six times 1:1 dilution of recombinant IFNT and native IFNT of different origins (rbIFNT 1c, rbIFNT 3a, CT-1 cell culture supernatant, embryo culture supernatant, uterine flushing).

\section{Endometrial stroma cell isolation and culture}

Endometrial stroma cells (SC) were isolated as described by Ulbrich et al. (2011). Briefly, healthy bovine luteal phase uteri according to the luteal stage of the ovary (Ireland et al. 1980) were collected at the local abattoir and kept on ice until further processing within $2 \mathrm{~h}$ after slaughter. The ipsilateral uterine horn was filled with sterile PBS containing $0.76 \%$ EDTA (Applichem, Darmstadt, Germany), and incubated in PBS for $1 \mathrm{~h}$ at $37^{\circ} \mathrm{C}$ under shaking conditions. The uterine horn was opened, and loosened epithelial cells were shaven away using a scalpel blade. With the help of a tweezer, the intercaruncular endometrium was dissected and incubated in $10 \mathrm{mg} / 25 \mathrm{~mL}$ collagenase solution (type IV collagenase in DMEM/F12) at $37^{\circ} \mathrm{C}$ for up to $3 \mathrm{~h}$ with constant stirring. The solution was then filtered through a tea sieve to remove any tissue debris and further filtered through a $40 \mu \mathrm{m}$ strainer (Greiner Bio-One, Kremsmünster, Austria) to receive SC. The SC were washed by centrifugation at $300 \mathrm{~g}$ for $8 \mathrm{~min}$ in $10 \mathrm{~mL}$ warm DMEM/ F12. Erythrocytes were removed by a 2-min incubation step in $2 \mathrm{~mL}$ lysis buffer $\left(156 \mathrm{mM} \mathrm{NH}_{4} \mathrm{Cl}, 0.13 \mathrm{mM}\right.$ Na-EDTA, $14 \mathrm{mM}$ $\mathrm{KCl}, \mathrm{pH}$ 7.4) (Merck). Afterwards, the SC were washed twice as mentioned above. Finally, the SC were resuspended in stroma cell culture medium (DMEM/F12 including 10\% FBS and 1\% penicillin-streptomycin) and counted on the automatic cell counter EVETM (Nano EnTek, Seoul, Korea). SC were plated at a concentration of $4 \times 10^{5}$ cells $/ \mathrm{mL}$ in $6 \mathrm{~cm}$ cell culture dishes (Greiner Bio-One, Kremsmünster, Austria) and cultured at $37^{\circ} \mathrm{C}$ and $5 \% \mathrm{CO}_{2}$ in air. The medium was changed every 48 h. After 3-10 days, the confluence state was reached and cells were split in a one to two ratio using trypsin solution (Thermo Fisher Scientific). A second passage was repeated $72 \mathrm{~h}$ later, and at confluence stage the cells were slowly frozen to $-80^{\circ} \mathrm{C}$ in freezing media $(70 \%$ DMEM/F12, $20 \%$ FBS, 10\% DMSO) using NalgenMr Frosty Freezing container (Thermo Fisher Scientific). We characterized aliquots of the endometrial SC morphologically by fluorescence microscopy. In pre-studies, endometrial SC and epithelial cells were stained by immunohistochemistry using vimentin and cytokeratin antibodies according to Gomez et al. (2018). Cells used in this study were isolated using the same procedure as in the prestudies and had the same morphology. 


\section{Stroma cell dose-response experiment}

The endometrial SC were tested for differential gene expression after exposure to IFNT. For this purpose, frozen SC in passage two after primary culture were thawn and $1 \times 10^{4}$ cells/well (Nunc 24-well, Thermo Fisher Scientific) cultured in SC culture medium at $5 \% \mathrm{CO}_{2}$ until confluency. After 4 days, the SC were washed with PBS and $400 \mu \mathrm{L}$ synthetic oviductal fluid (SOF) medium (Bernal-Ulloa et al. 2016b) supplemented with IFNT 1c $\left(5.8 \times 10^{8} \mathrm{IU} / \mathrm{mg}, 41 \mathrm{EU} / \mathrm{mg}\right)$ at seven different concentrations $\left(1 \times 10^{4}, 1 \times 10^{3}, 100,10,1,0.1,0.01 \mathrm{pg} / \mathrm{mL}\right)$ was added. The SC were then cultured in SOF medium at embryonic conditions $\left(38.8^{\circ} \mathrm{C}, 6 \% \mathrm{CO}_{2}\right.$ and $\left.6 \% \mathrm{O}_{2}\right)$. After $24 \mathrm{~h}$, cell culture supernatants were collected and frozen at $-80^{\circ} \mathrm{C}$, while the SC were evaluated and washed with PBS and stabilized with $350 \mu \mathrm{L}$ RNeasy lysis buffer (Qiagen) including $10 \%$ b-mercaptoethanol (BioRad) before freezing at $-80^{\circ} \mathrm{C}$. The experiment was carried out with SC of $n=3$ cattle and $n=3$ samples per cell donor for each IFNT concentration and respective negative sample. As additional bioavailability control samples, IFNT supplemented medium was frozen directly after the culture start or incubated without cells for $24 \mathrm{~h}$ at the same culture conditions as SC like mentioned above, respectively.

\section{Embryo-stroma cell co-culture experiment}

In order to investigate IFNT concentration and biological activity in a close to natural approach, we co-cultured embryos with endometrial SC. For this, $1 \times 10^{4} /$ well endometrial SC were cultured 5 days until the confluence stage. Medium containing FBS was removed, the SC were washed with warm PBS and $400 \mu \mathrm{L}$ SOF medium was added to each well. The SC were evaluated and cell culture inserts (pore diameter $3 \mu \mathrm{m}$, PET membrane, Greiner Bio-One, Kremsmünster, Austria) containing $100 \mu \mathrm{L}$ SOF were placed into each well and preincubated at $38.8^{\circ} \mathrm{C}, 6 \% \mathrm{CO}_{2}$ and $6 \% \mathrm{O}_{2}$.

Day 8 in vitro-produced expanded blastocysts were washed three times in TCM air. Pictures of the blastocysts were taken using an inverted microscope (Axiovert 40CFL microscope and DP73, Carl Zeiss AG) joined to a digital camera and (DP73, Olympus Corporation) and using the Cellsens Standard Softwaresoftware 1.18 (Olympus). Only expanded embryos were used for starting the cultured on day 8. Embryos were evaluated according to their morphologic appearance following the Manual of the International Embryo Transfer Society (Richard et al. 2015). The embryo size was determined, and after washing in SOF medium, each embryo was transferred into a separate co-culture insert and into a separate cell culture well to prevent any inter-embryo interference. The endometrial $\mathrm{SC}$ and IVF embryos were co-cultivated at $38.8^{\circ} \mathrm{C}, 6 \% \mathrm{CO}_{2}$ and $6 \% \mathrm{O}_{2}$ for $48 \mathrm{~h}$. On day 10 , pictures from the embryos were taken, and each blastocyst evaluated for signs of growing, expansion or degeneration and the size was determined in the insert. Afterwards embryos were washed in PBS supplemented with $0.1 \%$ polyvinyl alcohol (PVA), snap frozen and stored at $-80^{\circ} \mathrm{C}$ for further analyses. The cell culture supernatant of each well was collected and frozen at $-80^{\circ} \mathrm{C}$. The cells were first washed with PBS and stabilized with $350 \mu \mathrm{L}$ RNeasy lysis buffer (Qiagen) including 10\% b-mercaptoethanol before being frozen at $-80^{\circ} \mathrm{C}$. The experiment was carried out using ten embryos in co-culture with SC from $n=3$ different cows at $n=3$ independent days, resulting in 30 embryos per day per animal. For each animal and repetition, a control sample with SC plus insert lacking an embryo was carried out. Embryo size was determined using the size measurement tool of the software Cellsens Standard Software. The size was measured as the diameter of each embryo at two locations with $90^{\circ}$ difference. The average of these values was used for calculation. If a zona pellucida was present, the inner diameter of the zona pellucida was considered.

\section{Gene expression analysis}

\section{Reverse transcription and target preamplification in embryos}

Reverse transcription and target preamplification of embryonic genes was carried out using the CellsDirect One-Step qRTPCR kit (Thermo Fisher Scientific) as previously described (Nestorov et al. 2015, van der Weijden et al. 2017). In brief, $9 \mu \mathrm{L}$ of a reaction mix containing Superscript II Platinum Mix, Superase-In $(20 \mathrm{U} / \mu \mathrm{L}$, Thermo Fisher Scientific), a primer mix (including primer pairs for IFNT, MX2, ISG15, IFNAR1, SDHA, GAPDH and H3F3A), DNA resuspension buffer and $2 \times$ master mix Cells Direct was added to each embryo on ice and mixed for embryo lysis. The mix was transferred to a 96-well plate (BioRad Laboratories) and the preamplification started immediately (Lab Cycler, Sensoquest, Göttingen, Germany). Therefore, the plate was kept at $50^{\circ} \mathrm{C}$ for $15 \mathrm{~min}$ and heated up to $90^{\circ} \mathrm{C}$ for $2 \mathrm{~min}$. Fifteen amplification cycles of $15 \mathrm{~s}$ at $95^{\circ} \mathrm{C}$ and $4 \mathrm{~min}$ at $60^{\circ} \mathrm{C}$ followed. After preamplification, the reaction was cleaned up to remove all single-stranded DNA using Exonuclease I (20U/ $\mu \mathrm{L}$, Thermo Fisher Scientific). All samples were diluted 1:10 in nuclease free water and kept at $-20^{\circ} \mathrm{C}$ until RT-qPCR analysis. The RNA integrity of the embryo was not analysed due to the One-Step procedure that includes lysis and directly following reverse transcription in one tube. Own experience of our lab showed that embryos which are directly frozen after the experiment, as performed in this study, usually have a RIN $>9$. All samples were therefore used for analysis.

\section{RNA extraction and reverse transcription of SC}

The RNA extraction of SC from both the dose-response and co-culture was performed with the column-based RNeasy Mini Kit, including DNAse digestion (Qiagen), following the manufactures instructions. The RNA concentration was determined with the Nanodrop 2000 (Thermo Fisher Scientific) and RNA Integrity on a Bioanalyzer 2100 using RNA Nano Chip Assay (Agilent Technologies).

The reverse transcription was performed with $250 \mathrm{ng}$ total RNA, 50 units M-MLV H(-) point variant RT enzyme, $125 \mathrm{ng}$ random primers and $10 \mathrm{mM}$ dNTPs (Promega) per sample. The reaction mix was kept $10 \mathrm{~min}$ at $21^{\circ} \mathrm{C}$, followed by $50 \mathrm{~min}$ at $48^{\circ} \mathrm{C}$ and finally $15 \mathrm{~min}$ at $70^{\circ} \mathrm{C}$. All samples were processed simultaneously, and water and a RT enzyme negative control 
was included. Afterwards, all samples were diluted 1:1 in nuclease free water and stored at $-20^{\circ} \mathrm{C}$ until qPCR analysis.

\section{Embryonic sexing and analysis of gene expression ( $q P C R)$}

The determination of the sex of all 90 embryos was carried out as the first step of sample analysis in order to select an objective set of equally distributed male and female embryos. The basis for the decision was to select an equal number of embryos of each sex at each experiment day and for each stroma cell donor animal. Additionally, only good-quality embryos were chosen. Further sample processing and analysis of size, IFNT mRNA, protein concentration or biologically activity was performed only using the sex-selected and control samples and after sex selection.

All qPCR analysis steps were carried out using KAPA Universal SYBR green system (Kapa Biosystems, Woburn, USA) on a 384 Real-time system (BioRad Laboratories, Hercules, C100 Touch Thermal Cycler). The hot start reaction was initialized by 3 min incubation at $95^{\circ} \mathrm{C}$, followed by 40 cycles of $3 \mathrm{~s}$ at $95^{\circ} \mathrm{C}$ and $20 \mathrm{~s}$ at the appropriate annealing temperature. For primer sequences and annealing temperatures see Table 1. Embryos were sexed using the SRY gene, where the H3F3A gene served as a positive control. Melting temperatures and agarose gel analysis were used for data interpretation. Only samples with concordant data on melt temperature $\left(81\right.$ to $\left.81.5^{\circ} \mathrm{C}\right)$ and a size of $139 \mathrm{bp}$ were interpreted as male, whereas divergent or non-melting temperatures and no $139 \mathrm{bp}$ band evidence on an agarose gel were interpreted as female. All other combinations or negative $\mathrm{H} 3 \mathrm{~F} 3 \mathrm{~A}$ control remained undefined and were excluded from further analyses. After sexing, gene expression profiles of selected samples were analysed.

\section{Embryonic and stroma cell qPCR data analysis}

The relative gene expression of genes of interest (GOI) (IFNT, MX2, ISG 15, IFNAR1 for embryos and MX2, ISG15, OAS1 and IFNAR1 for SC) were analysed using the method described by Pfaffl (2001) and following the MIQE guidelines (Bustin et al. 2009). Only total IFNT expression was analysed using RT-qPCR; a discrimination of IFNT variants was not performed. For normalization, the geometric mean stable expression of the reference genes (SDHA, GAPDH and H3F3A) was verified and used in embryo samples analysis, whereas H3F3A,
YWAHZ and $U B Q 3$ were used in SC analysis $\left(\triangle \mathrm{Ct}=\mathrm{Ct}_{\mathrm{GOI}}-\right.$ $\left.\mathrm{Ct}_{\text {geomean reference genes }}\right)$. Embryonic gene expression is displayed as $15-\Delta$ ct. In SC gene expression analysis, the relative gene expression to the control samples of corresponding SC donors was calculated $\left(\Delta \Delta \mathrm{ct}=\Delta \mathrm{ct}_{\text {sample }}-\Delta \mathrm{ct}_{\text {control }}\right)$. Fold-change differences were assessed by $2^{-\Delta \Delta c t}$.

\section{IFNT concentration determination (ELISA)}

For total IFNT concentration determination a 96-well flatbottom plate (Thermo Fisher Scientific, Waltham, USA) was first coated with $200 \mathrm{ng} /$ well capture antibody in coating buffer $\left(15 \mathrm{mM} \mathrm{Na}_{2} \mathrm{CO}_{3} \times 10 \mathrm{H}_{2} \mathrm{O}, 35 \mathrm{mM} \mathrm{NaHCO}\right.$, $\mathrm{pH}$ 9.6) by incubation overnight at $4{ }^{\circ} \mathrm{C}$ under shaking conditions. Unbound capture antibody was removed, and the plate blocked with $300 \mu \mathrm{L} /$ well blocking buffer (1\% skim milk powder in PBS, $\mathrm{pH}$ 7.4) for $1 \mathrm{~h}$ at room temperature (RT) under shaking conditions. The plate was then washed two times with $0.05 \%$ Tween 80 solution in a plate washer (405 select microplate washer, Biotek Instruments, Germany). One hundred microliters of each sample (in case high concentration was expected, the sample was diluted in SOF medium) and $100 \mu \mathrm{L}$ of seven antigen standards (rb IFNT $1 \mathrm{c}+\mathrm{rb}$ IFNT $3 \mathrm{a}$ diluted in SOF) from $1 \mathrm{ng} / \mathrm{mL}$ to $10 \mathrm{pg} / \mathrm{mL}$ plus a 0 -value (SOF medium) were pipetted in duplicates and incubated for $2 \mathrm{~h}$ at RT under shaking conditions. The plate was washed twice and $100 \mu \mathrm{L}$ of $20 \mathrm{ng} / 100 \mu \mathrm{L}$ biotinylated detection antibody in $\mathrm{AB}(0.1 \%$ skim milk powder in PBS, $\mathrm{pH} 7.4)$ was added to each well, and again incubated for $2 \mathrm{~h}$ shaking at RT. Unbound detection antibody was removed by washing twice. Thereafter, $100 \mu \mathrm{L}$ of $1: 240$ in $\mathrm{AB}$ diluted Streptavidin-HRP (Roche AG, Basel, Switzerland) was added to each well. Following incubation for $15 \mathrm{~min}$ in the dark at RT under shaking conditions, the plate was thoroughly washed four times. Finally, $150 \mu \mathrm{L}$ of tetramethylbenzidine dihydrochloride (TMB) substrate (Carl Roth) was added to each well and the reaction was incubated for $40 \mathrm{~min}$ at RT under shaking conditions in the dark. The reaction was stopped with $50 \mu \mathrm{L} /$ well $2 \mathrm{M}$ sulphuric acid and measured at $\mathrm{OD}_{450}$ (Cytation 3 image reader, Biotek Instruments). The concentrations were calculated in the linear range of the standard curve using the formula $\mathrm{OD}_{450}=\mathrm{A} \times$ concentration $+\mathrm{B}$ (Gen5 software, Version 2.05, Biotek Instruments). All data points below the LOD were calculated as the LOD $(7.3 \mathrm{pg} / \mathrm{mL})$ for statistical analysis.

Table 1 Primers used for gene expression analysis in bovine endometrial stroma cells and blastocysts.

\begin{tabular}{|c|c|c|c|c|c|}
\hline \multirow[b]{2}{*}{ Gene ID } & \multirow[b]{2}{*}{ Sample type } & \multirow[b]{2}{*}{ Accession number } & \multirow{2}{*}{$\begin{array}{c}\text { Annealing } \\
\text { temperature }\left({ }^{\circ} \mathrm{C}\right)\end{array}$} & \multicolumn{2}{|c|}{ Primer sequences } \\
\hline & & & & Forward & Reverse \\
\hline$S R Y$ & Embryo & NM_001014385 & 60 & GAACGCTTTCATTGTGTGGTC & GAAGAATGGGCGCTTTTCGG \\
\hline SDHA & Embryo & NM_174178 & 60 & GCAGAACCTGATGCTTTGTG & CGTAGGAGAGCGTGTGCTT \\
\hline GAPDH & Embryo & NM_001034034 & 60 & GGTCACCAGGGCTGCTTTTA & CCAGCATCACСССАСТTGAT \\
\hline IFNT & Embryo & NM_001015511 & 54 & GATCCTTCTGGAGCTGGYTG & GCCCGAATGAACAGACTCTC \\
\hline H3F3A & Embryo, Stroma & NM_001014389 & 60 & ACTGGCTACAAAAGCCGСTC & АСТTGССТССТGСАААGСАС \\
\hline IFNAR 1 & Embryo, Stroma & NM_174552 & 60 & СTCCAGTCATCAGCGTGAAA & GTGCTCTGGCTTTGACACAA \\
\hline$M \times 2$ & Embryo, Stroma & NM_173941 & 57 & CTTCAGAGACGCCTCAGTCG & TGAAGCAGCCAGGAATAGTG \\
\hline ISG15 & Embryo, Stroma & NM_174366 & 60 & ACTCCATGACGGTATCCGAG & ACССTTGTCGTTCCTCAC \\
\hline OAS1 & Stroma & NM_178108 & 60 & CAGGAGGTGGAGTTCGATGT & GATGAGGCTCTTCAGCTTGG \\
\hline$U B Q 3$ & Stroma & NM_174133 & 57 & AGATCCAGGATAAGGAAGGCAT & GCTCCACСTCCAGGGTGAT \\
\hline YWAHZ & Stroma & NM_174814 & 60 & AGGCTGAGCGATATGATGAC & GACССТССАAGATGACСТAC \\
\hline
\end{tabular}




\section{IFNT biological activity and stroma cell sensitivity to IFNT stimulation}

The SC gene expression response was considered as biological activity of IFNT. The linear range of ISG expression response to the IFNT stimulation in the SC dose-response experiment was calculated by evaluating the $R^{2}$ value of linear regression with fold-change data of each gene (ISG 15, MX2, OAS1). The highest and lowest linear concentrations were determined if the $R^{2}$ value between the corresponding values were higher than 0.97 . The sensitivity was assessed by calculation of the $\Delta$ ct first being significantly different from 0 . All these values were within the linear range.

\section{Statistical analysis}

All data were statistically analysed using the Addln software XLSTAT Version 2018.1 (Addinsoft SARL, Paris, France) in Excel 2016 MSO (Microsoft, Washington, USA). All data are displayed as mean \pm S.D. Whiskers in the box plot diagrams were created with the software IBM SPSS Statistics 23 and display the $95 \%$ confidence intervals $(\mathrm{Cl})$. The $P$-values in the embryostroma-cell co-culture were calculated using two sample Student's $t$-test or Mann-Whitney test analysis considering normal distribution calculated with the Kolmogorov-Smirnov test. In the dose-response experiment a generalized linear mixed model was used to test for statistically significant gene expression induction as a consequence of IFNt exposure (RStudio, Version 1.1.456). The concentration was used as fixed effect, and the animal and replicate were included as random factors. The statistical differences in gene expression levels between different exposure groups were assessed by an ANOVA with Tukey post-hoc test (Bretz et al. 2010). Values $<0.05$ were considered as statistically significant. Correlation analysis was carried out using Pearson correlation. XLSTAT software was used for the discriminant analysis including cross validation. The qPCR data from samples with divergent melting temperatures or lost samples were not included for sample analysis.

\section{Results}

\section{Method validation}

\section{IFNT-translation: ELISA}

The two most superior polyclonal rabbit anti-IFNT 1c and the anti-IFNT $3 a$ antibodies were selected for the establishment and validation of a sandwich ELISA. Both antibodies efficiently detected either variant of IFNT but were not able to discriminate them. For this reason, only total IFNT concentration was assessed with the ELISA. The detection limit (LOD) of the immunoassay was $7.3 \mathrm{pg} / \mathrm{mL}$, while the quantification limit (LOQ) was $24.9 \mathrm{pg} / \mathrm{mL}$. Above the LOQ, the recovery, the inter-assay precision and intra-assay precision were below $12 \%$. Cross reactivity $(4 \%)$ was only detected against the most closely related IFNW, whereas all other prominent and related IFN were not detected.
The dilution of the different matrices including uterine flushing, DMEM $/ 12+10 \%$ FBS, and SOF medium did not influence the linear detection of IFNT. Native IFNT was detected parallel and in the same dynamic as the recombinant IFNT standard (Supplementary Table 1, see section on supplementary data given at the end of this article). The recovery rate within the quantification range of IFNT protein after $24 \mathrm{~h}$ incubation with endometrial SC was $85 \pm 11 \%$.

\section{IFNT biological activity: stromal gene expression response to dose-dependent IFNT stimulation}

RNA integrity (RIN) of the SC was between 9.8 and 10. This excellent quality allowed further analysis of all samples. To assess the sensitivity of the SC gene expression response to IFNT, the gene expression of three ISG (MX2, ISG15, OAS1) was determined (Fig. 1). A dose-dependent increase in gene expression was observed for all three genes. OAS1 showed a saturation for more than $10 \mathrm{pg} / \mathrm{mL}$, followed by ISG 15 at $100 \mathrm{pg} /$ $\mathrm{mL}$ and $M X 2$ non at $1 \times 10^{4} \mathrm{pg} / \mathrm{mL}$ IFNT. Fold-change differences due to IFNT stimulation ranged from 760fold (ISG15) and 710-fold (OAS1) to 25086-fold (MX2) at $1 \times 10^{4} \mathrm{pg} / \mathrm{mL}$ IFNT compared to the control. MX2 presented the largest linear quantification range, covering three orders of magnitude $\left(10-1 \times 10^{4} \mathrm{pg} /\right.$ $\mathrm{mL}$ ), while ISG15 and OAS1 covered two orders of magnitude $(1-100 \mathrm{pg} / \mathrm{mL}$ and OAS1 $(0.1-10 \mathrm{pg} / \mathrm{mL}))$. While the SC of all three animals showed similar MX2 and ISG 15 expression, one animal showed significantly higher gene expression of OAS1 after IFNT stimulation.

\section{Embryo-stroma-co-culture experiment}

\section{Embryo sexing and characterisation}

A total of 719 bovine oocytes were used for embryo production in three different replicates. The total average cleavage rate for the in vitro embryo production processes was $73.6 \pm 1.0 \%$ and the blastocyst rate at day 8 of development was $37.1 \pm 5.9 \%$. A total of $48.8 \%$ of the blastocysts were classified as female, $40.0 \%$ as male and $11.1 \%$ remained undefined. The majority of all embryos hatched during the two days of co-culture $(83.3 \%)$. Only $2.2 \%$ of embryos did show signs of apoptosis, or a lack in size increase, and were therefor considered as nondeveloping to display blastocysts (Table 2). In order to include only equally viable embryos for further data analysis, only hatched or hatching blastocyst of good morphological quality were used. Furthermore, the ratio of female/male embryos, experimental repeats, and SC donors was balanced.

On day 8, male embryos were slightly, but significantly smaller than female embryos $(180 \pm 20 \mu \mathrm{m}$ vs $194 \pm 21 \mu \mathrm{m}, P=0.018)$. At day 10 , the sizes were not different ( $284 \pm 41 \mu \mathrm{m}$ vs $278 \pm 48 \mu \mathrm{m}, P>0.05)$ (Fig. $2 \mathrm{~A}$ ). 


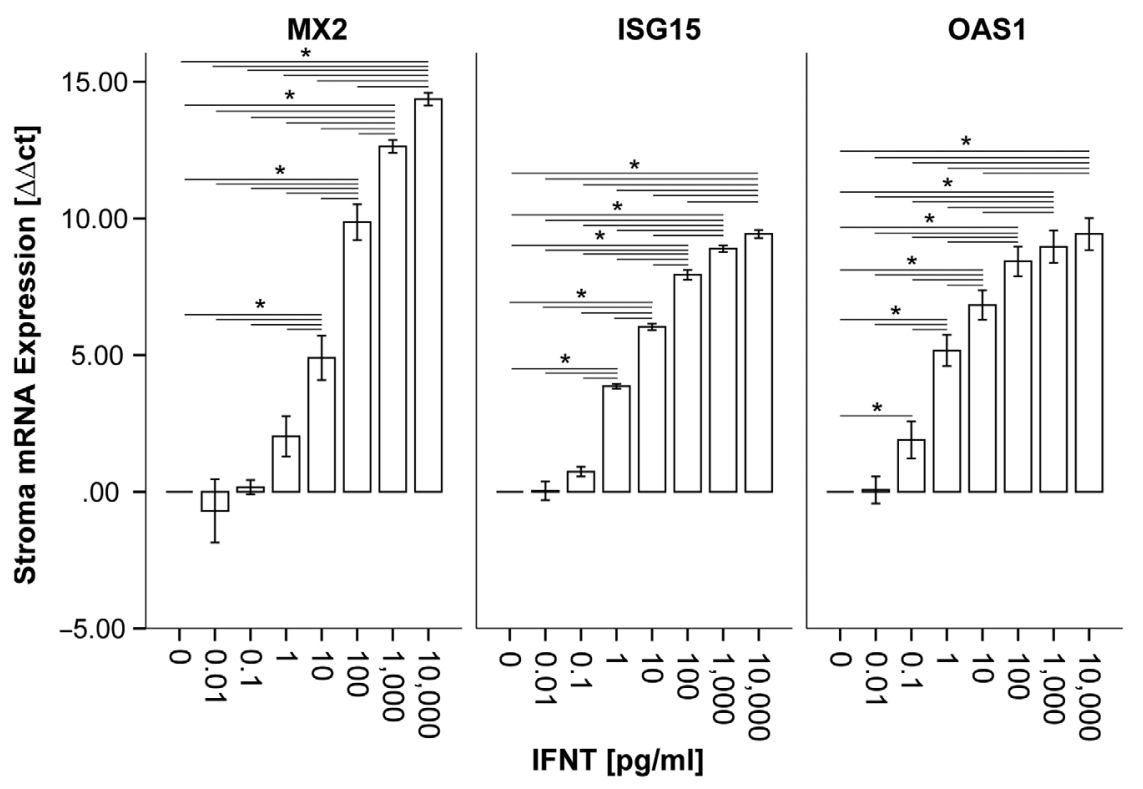

Figure 1 Stroma gene expression analyses. Values are shown as $\Delta \Delta \mathrm{ct}$, error bars are shown as S.E.M. * Significantly $(P<0.05)$ different values between the stimulation concentrations. $n=9$ for every concentration including $n=3$ biological replicates for each of the $n=3$ SC donor animals.

\section{Embryonic transcription}

Female day 10 blastocysts displayed a 5.6-fold significantly higher transcription level of IFNT than males $(P<0.0001)$ after 2 days of co-culture with endometrial SC. A significant difference was likewise detected in the interferon receptor expression between female and male blastocysts $(1.3$-fold, $P=0.045)$. The expression of MX2 and ISG15 genes did not differ between male or female blastocysts (Fig. 2B). A statistically significant correlation was observed between IFNAR1 and MX2 $(P=0.013$, Pearson correlation coefficient $=0.34)$ and between MX2 and ISG15 ( $P=0.003$, Pearson correlation coefficient $=0.41$ ) gene expression levels. IFNT expression was neither significantly correlating with its receptor IFNAR1 nor with ISC (Table 3).

\section{Translation of IFNT}

A highly significantly $(3.6$-fold, $P<0.0001)$ different concentration of IFNT was determined in the supernatant of female $(42.0 \pm 33.4 \mathrm{pg} / \mathrm{mL})$ vs male $(11.6 \pm 8.6 \mathrm{pg} / \mathrm{mL})$ embryos after $48 \mathrm{~h}$ of co-culture with endometrial SC (Fig. 2C). The concentrations of all control samples was below the LOQ $(8.4 \pm 2.0 \mathrm{pg} / \mathrm{mL})$.

\section{Stromal gene expression response and IFNT biological activity}

Female and male blastocysts induced differential mRNA expression of all three ISG (OAS1, ISG15 and MX2) in endometrial SC after $48 \mathrm{~h}$ of co-culture $(1.8$-fold, $P=0.0004 ; 2.4$-fold, $P=0.0001$ and 5.2-fold, $P<0.0001$, respectively) (Fig. 2D). Additionally, the gene expression profiles for all three ISG strongly correlated with each other ( $P$-value $<0.0001$, Pearson correlations between 0.73 and 0.80 ) (Table 3$)$.
Fold changes between male and female embryos

The IFNT gene expression (5.6-fold), as well as protein concentrations in cell culture supernatant (3.6-fold), and IFNT biological activity (5.2-fold) was higher in female than in males (Fig. 2B, C and D). For biological activity, only the SC gene expression of MX2 is shown, as the transcript abundance of all samples was within the genespecific linear expression range, whereas for ISG15 and OAS 1 only 21 or $79 \%$, respectively, of the samples were within the saturated gene expression and could thus not be adequately quantified.

\section{Correlation analysis of the parameters}

The IFNT gene expression in day 10 blastocysts was correlated with the IFNT protein concentration in co-culture supernatants $(P<0.0001$, Pearson correlation coefficient $=0.59$ ), and ISG15, OAS1, and MX2 gene expression in SC $(P=0.002, P=0.0006, P<0.0001$ and Pearson correlation coefficients $=0.42,0.46$ and 0.61 , respectively) (Table 3). Additionally, we observed that IFNAR1 expression in endometrial SC was independent from all other measured embryonic transcripts. The transcription profiles of ISG15, MX2 and IFNAR1 in day 10 blastocyst correlated neither with endometrial SC gene expression, nor IFNT concentration, nor embryo size.

\section{Embryo sex determination}

A discriminant analysis for sex separation was conducted for each measured sample type separately using the evaluated parameters (Table 4). While 50\% accuracy would reflect a random choice, $100 \%$ accuracy would perfectly discriminate male and female embryos. The determination of embryo sex by size only slightly increased a random choice $65 \%$ accuracy in male and 
Table 2 Bovine blastocyst classification 10 days after IVF including 2 days of co-culture.

\begin{tabular}{lccccc}
\hline & Total no. of blastocysts $(\%)$ & Hatched $(\%)$ & Hatching $(\%)$ & Not hatched $(\%)$ & No further development $(\%)$ \\
\hline Male & $36(40)$ & $29(81)$ & $1(3)$ & $4(11)$ & $2(6)$ \\
Female & $44(49)$ & $36(82)$ & $5(11)$ & $3(7)$ & $0(0)$ \\
Undefined & $10(11)$ & $10(100)$ & $0(0)$ & $0(0)$ & $0(0)$ \\
Total & $90(100)$ & $75(83)$ & $6(7)$ & $7(8)$ & $2(2)$ \\
\hline
\end{tabular}

Bovine embryos at the expanded blastocyst stage on day 8 after IVF. Number and (\%) of developmental stages in male and female embryos.

female, respectively). Considering only IFNT protein concentration, male embryos were predicted with $88 \%$ accuracy, while the selection of female embryos by IFNT concentration was not predictable (48\% accuracy). The SC response $(\Delta \Delta \mathrm{ISG} 15, \Delta \Delta \mathrm{MX} 2$ and $\Delta \Delta \mathrm{OAS})$ indicating IFNT activity on the other hand predicted female embryos better than male embryos $(80 \%$ and $62 \%$ accuracy, respectively). The best sex estimation was observed by transcript analyses at the blastocyst stage (male $88 \%$ and female $72 \%$ accuracy).

\section{Discussion}

\section{Validation of IFNT ELISA and stromal ISG expression response to IFNT}

We established a very sensitive and specific ELISA to detect minute amounts of bovine IFNT in cell culture medium and uterine flushings. This is indicated by the lack of cross reactivity to IFNA, IFNB and IFNG and only $4 \%$ cross reaction to IFNW. The assay performance was within an acceptable variation range. The LOD was
$7.3 \mathrm{pg} / \mathrm{mL}$ and thus about 1000 times more sensitive than the RIA described by Takahashi et al. (2005) and five times more sensitive than the RIA reported by Romero et al. (2015). Unlike the antigen used by Takahashi and co-workers, our recombinant IFNT expressed in E. coli was not glycosylated. However, the developed antibodies detected native IFNT in a parallel serial dilution identical to the recombinant IFNT. Additionally, the ELISA was biologically validated by demonstrating the sexual dimorphism in IFNT secretions of bovine blastocysts at the protein level.

It is well known that the paracrine action of IFNT is mediated, and greatly amplified, by cell signalling of endometrial cells. Many cells, including immune cells and endometrial SC, react to an interferon stimulation by differential gene expression of classical ISG, and it has been shown to be directly related to the interferon activity (Moll et al. 2011). However, the reaction may be differently pronounced. Only recently Talukder et al. showed that bovine oviductal epithelial cells (BOECs) do not react to low amounts of IFNT secreted by day 4 embryos, whereas polymorph bovine mononuclear
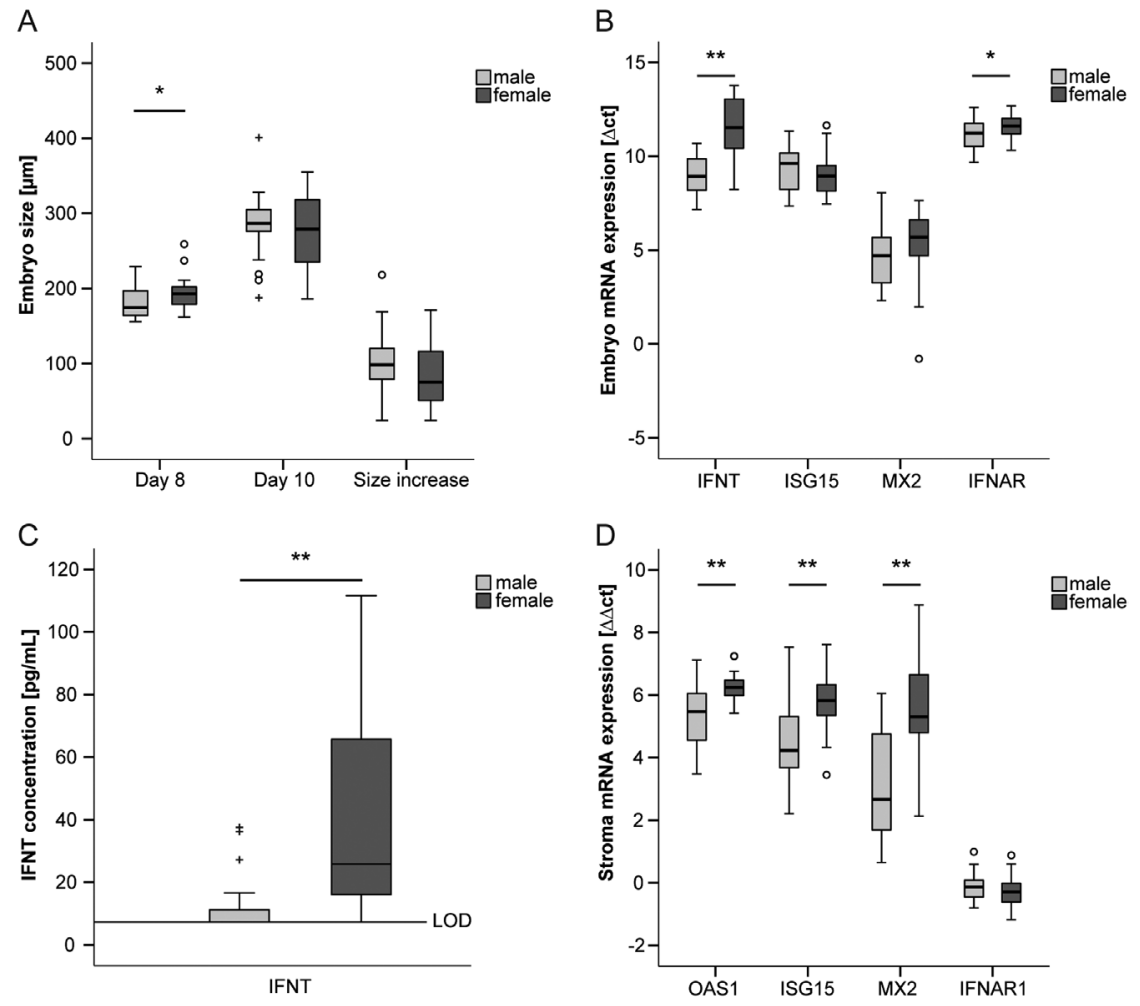

Figure 2 Effects of embryonic sex on: (A) blastocyst size on days 8 and 10 and individual size increase during $48 \mathrm{~h}$ co-culture; (B) embryonic gene expression of IFNT, MX2, ISG 15 and IFNAR 1 on day 10 (qPCR data are shown as $15-\Delta \mathrm{Ct}$ ); (C) IFNT concentration measured in the cell culture supernatant after $48 \mathrm{~h}$ of co-culture with day 8 blastocysts and (D) endometrial stroma cell gene expression of MX2, OAS1, ISG15 and IFNAR 1 after $48 \mathrm{~h}$ co-culture with day 8 blastocysts ( $\mathrm{qPCR}$ data are shown as $\Delta \Delta \mathrm{Ct}$ ). Data of $n=26$ female and $n=26$ male embryo co-cultures are shown. The 25th percentile and the 75th percentile as well as the median are represented in the box plots. The whiskers correspond to the $95 \% \mathrm{Cl}$ of the data. Points represent outliers while a ' + ' represents the extreme outliers. Significances are indicated as ${ }^{*} P<0.05,{ }^{* *} P<0.001$. 


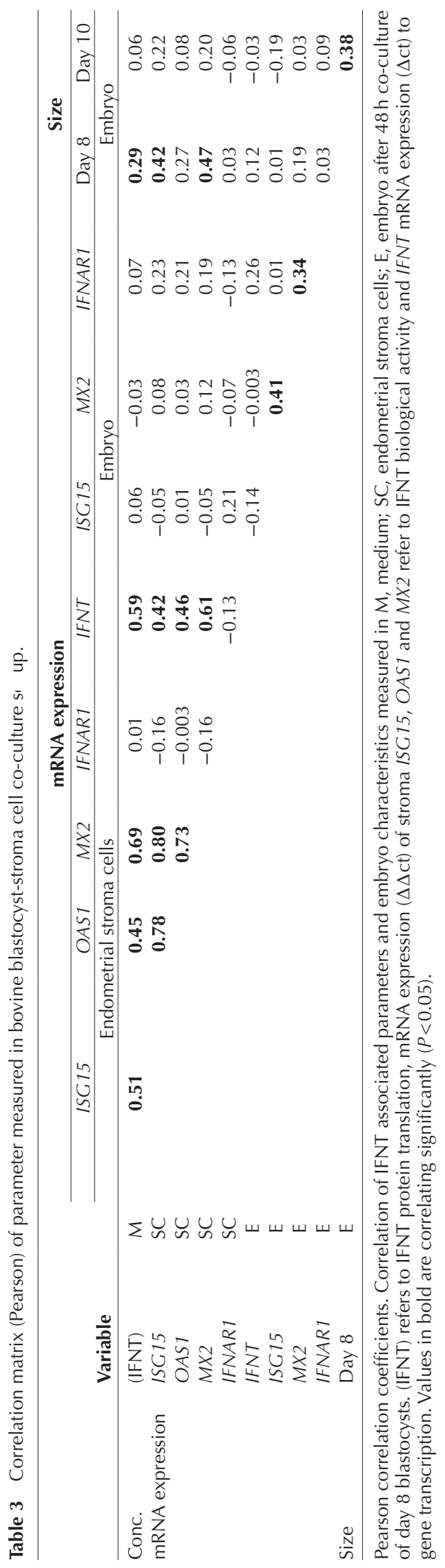

cells do (Talukder et al. 2018). We chose endometrial SC within an embryo co-culture model to quantify the action of minute amounts of IFNT as they are known to react sensitively to IFNT by classical ISG expression (Johnson et al. 1999, Forde et al. 2011). Additionally, we see the advantage that these cells are part of the natural environment of bovine blastocysts and thus believe the cells may positively influence physiological development. We analysed the dose-response expression of three ISGs. The primary cells were chosen from bovine uteri at the mid luteal stage, the time when the ISG response is most pronounced (Shirozu et al. 2017). The ISG gene expression increased with increasing IFNT stimulation and was distinctly ISG dependent. MX2 displayed the widest range of differential gene expression and allowed a quantification over three orders of magnitude from $10 \mathrm{pg} / \mathrm{mL}$ to $1 \times 10^{4} \mathrm{pg} / \mathrm{mL}$ IFNT. OAS1 displayed the most sensitive differential expression as low as $0.1 \mathrm{pg} / \mathrm{mL}$, which is more than 100-fold lower than reported of a MDBK cell-based reporter gene assay (Toji et al. 2017). Thus, our results show that this is a simple, but very effective and secure model to investigate the IFNT biological activity. Our co-culture model using endometrial SC detects very small amounts of IFNT while it is easy to handle at the same time. Moreover, the co-culture model provides a physiological environment to the embryo, including signalling exchange between embryo and cells, which generally improves developmental conditions for the in vitro method (Melnick \& Spandorfer 2015) including the induction of IFNT in Day 4 embryos co-cultured with bovine oviduct endometrial cells (Talukder et al. 2018). However, as the SC are primary cultures derived from donor animals, the present assay is labdependent, and thus standardisation is challenging. In addition, in contrast to the ELISA, the ISG stimulation is not IFNT specific, but may indicate any kind of type 1 interferon stimulation.

To determine the amounts of IFNT produced by the cultured embryos, the co-culture model held both the possibility to analyse the induction of gene expression and the protein abundance. A slight underestimation of IFNT concentration in the ELISA may have occurred as SC are able to metabolize IFNT or inhibit antibody recognition by other means.

\section{Correlation between IFNT transcription, IFNT translation, IFNT activity and sex}

A sex-dependent difference in antiviral activity of blastocysts supernatants has been observed in several studies (Larson et al. 2001, Kubisch et al. 2003, Kimura et al. 2004a). However, differential IFNT gene expression between day 8 male and female blastocysts has not been previously reported (Walker et al. 2009). Even though the authors analysed different mRNA variants, these were not differentially expressed 
Table 4 Sex determination for bovine blastocysts in a co-culture system.

\begin{tabular}{lccccc}
\hline & Embryo-SC supernatant & SC & Embryo & Embryo & Combination of parameters \\
\cline { 2 - 6 } & IFNT concentration & IFNT activity & IFNT mRNA & size & Concentration activity mRNA size \\
\hline \% Accuracy & & & & & \\
Female & 48.0 & 80.0 & 72.0 & 65.4 & 73.9 \\
Male & 88.5 & 62.5 & 88.5 & 65.4 & 83.3 \\
Total & 68.6 & 71.4 & 80.4 & 65.4 & 78.7 \\
\hline
\end{tabular}

Discriminant analysis including cross validation of IFNT-depending variables in bovine blastocysts. IFNT concentration (IFNT) measured in endometrial stroma cell-embryo co-culture supernatant, IFNT activity measured in endometrial stroma cells $(\Delta \Delta \mathrm{ct}$ ISG $15, \Delta \Delta \mathrm{ct} O A S 1, \Delta \Delta \mathrm{ct}$ MX2), IFNT mRNA expression ( $\triangle$ ct IFNT) measured in day 10 after IVF blastocysts, size of day 8 and 10 after IVF blastocysts. The last column shows the accuracy of sex determination with inclusion of all parameters into the discriminant analysis.

depending on the sex. Thus, it was not possible to present an explanation for the IFNT activity differences (Walker et al. 2009). Different variants exhibit different potencies, fluctuating between 3 to $11 \mathrm{IU} / \mathrm{mg}$ (Ealy et al. 2001). Therefore, it is possible that the increase of a specific, high potent variant in one sex leads to an increase of antiviral activity in that sex, even though total IFNT protein expression remains similar between both sexes. We postulated that if activity levels were sexdependent due to increased potency of IFNT variants, the protein concentration would be independent from the activity and not differential between sexes. However, the antibodies generated in the current study were not capable of differentiating between the variants. Nevertheless, we have shown that day 10 blastocysts express IFNT mRNA and protein, which correlate with the gene expression of IFNT downstream targets. Additionally, we have demonstrated that fold changes of IFNT production between female and male blastocysts are in a similar range for all three parameters (six-, four- and five-fold, respectively). It is possible that the lower fold-change of the protein concentration may be underestimated, as many male blastocysts secreted concentrations below the LOD. We conclude that female blastocysts most likely have an increased IFNT gene expression, that irrespective of the potency of the variant, results in higher protein concentrations that lead to the sex-dependent activity levels.

In agreement with previous reports, a sex-dependent difference in IFNT production and activity was evident. However, there were very high variations among both the IFNT production and the biological activity, demonstrating variation in antiviral activity (Kimura et al. 2004a). Consequently, female and male blastocysts could not be discriminated effectively by these parameters. IFNT concentration measurement or IFNT activity measurement may only increase the probability to select a male blastocyst or a female.

According to Kimura et al. (2004b), the IFNT production is independent on the cell number at the blastocyst stage, as female blastocysts have less cells than males, but produce more IFNT. We additionally show that increased size is not related to increased IFNT production, as there were no size differences between sexes at day 10, even though differential IFNT production was evident. This indicates that the IFNT expression and translation pattern is changing during embryo development. At the blastocyst stage, the minute amounts of IFNT seem to be secreted independently of the size and cell number, but clearly related to the embryonic gene expression level. Later, at the time of the peak in IFNT production by the elongated embryo at preimplantation, the embryonic size is related to IFNT production, whereas its mRNA expression is not (Robinson et al. 2006, Barnwell et al. 2016).

Although the paracrine action of IFNT on the endometrium has been studied intensively, the role of autocrine stimulation of the embryo is still under investigation (Wang et al. 2013, Brooks \& Spencer 2015). We identified expression of ISG and IFNAR1 transcripts in the blastocysts; yet, a sex-specific ISG expression difference was not apparent. Our results do not give information about IFNT self-stimulation by the embryo. Nevertheless, as IFNT production and embryonic ISG expression were not correlated, it seems likely that the ISG expression in the embryo was not influenced by IFNT present in the medium. This observation corroborates the results from Imakawa et al., showing the lack of IFNT binding to the embryonic IFNAR before day 16 in ovine conceptuses (Imakawa et al. 2002).

In conclusion, the biological validation of our in-house developed ELISA detecting minute amounts of IFNT was assessed by employing a cell-embryo co-culture system, which evidences sex-specific IFNT protein expression. We showed a direct correlation between the embryonic IFNT mRNA expression level, the protein concentration and the biological activity at the hatched blastocyst stage. Collectively, these results demonstrated sex dependency for all three parameters. Thus, female blastocysts most likely have an increased IFNT gene and protein expression rather than more potent IFNT variants.

\section{Supplementary data}

This is linked to the online version of the paper at https://doi.org/10.1530/REP-18-0312. 


\section{Declaration of interest}

The authors declare that there is no conflict of interest that could be perceived as prejudicing the impartiality of the research reported.

\section{Funding}

This work was partly funded by the 'Bayrische Staatsministerium für Ernährung Landwirtschaft und Forsten' (München, Germany) and by the ETH Zurich Research Grant ETH-53 16-1. The funders had no role in study design, data collection and analysis, decision to publish, or preparation of the manuscript.

\section{Acknowledgements}

The authors thank Christine Fochtmann, Waltraud Schmid and Brigitte Dötterböck for their help in antibody generation and Christoph Schanzenbach at the Chair of Biopolymer Chemistry, TU Munich, for providing the E. coli strains and plasmids for protein expression and help in transformation.

\section{References}

Barnwell CV, Farin PW, Ashwell CM, Farmer WT, Galphin SP Jr \& Farin CE 2016 Differences in mRNA populations of short and long bovine conceptuses on Day 15 of gestation. Molecular Reproduction and Development 83 424-441. (https://doi.org/10.1002/mrd.22640)

Bazer FW, Burghardt RC, Johnson GA, Spencer TE \& Wu G 2008 Interferons and progesterone for establishment and maintenance of pregnancy: interactions among novel cell signaling pathways. Reproductive Biology 8 179-211. (https://doi.org/10.1016/S1642-431X(12)60012-6)

Bazer FW, Ying W, Wang X, Dunlap KA, Zhou B, Johnson GA \& Wu G 2015 The many faces of interferon tau. Amino Acids 47 449-460. (https://doi. org/10.1007/s00726-014-1905-x)

Bermejo-Alvarez P, Rizos D, Lonergan P \& Gutierrez-Adan A 2011 Transcriptional sexual dimorphism in elongating bovine embryos: implications for $\mathrm{XCl}$ and sex determination genes. Reproduction 141 801-808. (https://doi.org/10.1530/REP-11-0006)

Bernal-Ulloa SM, Heinzmann J, Herrmann D, Hadeler KG, Aldag P, Winkler S, Pache D, Baulain U, Lucas-Hahn A \& Niemann H 2016 a Cyclic AMP affects oocyte maturation and embryo development in prepubertal and adult cattle. PLOS ONE 11 e0150264. (https://doi. org/10.1371/journal.pone.0150264)

Bernal-Ulloa SM, Lucas-Hahn A, Herrmann D, Hadeler K-G, Aldag P, Baulain U \& Niemann H $2016 b$ Oocyte pre-IVM with caffeine improves bovine embryo survival after vitrification. Theriogenology $\mathbf{8 6}$ 1222-1230. (https://doi.org/10.1016/j.theriogenology.2016.04.013)

Bernal SM, Heinzmann J, Herrmann D, Timmermann B, Baulain U, Großfeld R, Diederich M, Lucas-Hahn A \& Niemann H 2015 Effects of different oocyte retrieval and in vitro maturation systems on bovine embryo development and quality. Zygote 23 367-377. (https://doi. org/10.1017/S0967199413000658)

Bretz F, Hothorn T \& Westfall P 2010 Multiple Comparisons Using R. Boca Raton: CRC Press.

Brooks K \& Spencer TE 2015 Biological roles of interferon tau (IFNT) and type I IFN receptors in elongation of the ovine conceptus. Biology of Reproduction 92 47. (https://doi.org/10.1095/biolreprod.114.124156)

Bustin SA, Benes V, Garson JA, Hellemans J, Huggett J, Kubista M, Mueller R, Nolan T, Pfaffl MW, Shipley GL et al. 2009 The MIQE guidelines: minimum information for publication of quantitative realtime PCR experiments. Clinical Chemistry 55 611-622. (https://doi. org/10.1373/clinchem.2008.112797)

Choi Y, Johnson GA, Burghardt RC, Berghman LR, Joyce MM, Taylor KM, Stewart MD, Bazer FW \& Spencer TE 2001 Interferon regulatory factor-two restricts expression of interferon-stimulated genes to the endometrial stroma and glandular epithelium of the ovine uterus. Biology of Reproduction 65 1038-1049. (https://doi.org/10.1095/ biolreprod65.4.1038)

Ealy AD, Larson SF, Liu L, Alexenko AP, Winkelman GL, Kubisch HM, Bixby JA \& Roberts RM 2001 Polymorphic forms of expressed bovine interferon-tau genes: relative transcript abundance during early placental development, promoter sequences of genes and biological activity of protein products. Endocrinology 142 2906-2915. (https://doi. org/10.1210/endo.142.7.8249)

Farin CE, Imakawa K \& Roberts RM 1989 In situ localization of mRNA for the interferon, ovine trophoblast protein-1, during early embryonic development of the sheep. Molecular Endocrinology 3 1099-1107. (https://doi.org/10.1210/mend-3-7-1099)

Farin CE, Imakawa K, Hansen TR, McDonnell JJ, Murphy CN, Farin PW \& Roberts RM 1990 Expression of trophoblastic interferon genes in sheep and cattle. Biology of Reproduction 43 210-218. (https://doi. org/10.1095/biolreprod43.2.210)

Forde N, Carter F, Spencer TE, Bazer FW, Sandra O, Mansouri-Attia N, Okumu LA, McGettigan PA, Mehta JP, McBride R et al. 2011 Conceptusinduced changes in the endometrial transcriptome: how soon does the cow know she is pregnant? Biology of Reproduction 85 144-156. (https://doi.org/10.1095/biolreprod.110.090019)

Forde N, Maillo V, O'Gaora P, Simintiras CA, Sturmey RG, Ealy AD, Spencer TE, Gutierrez-Adan A, Rizos D \& Lonergan P 2016 Sexually dimorphic gene expression in bovine conceptuses at the initiation of implantation. Biology of Reproduction 95 92. (https://doi.org/10.1095/ biolreprod.116.139857)

Fray MD, Mann GE \& Charleston B 2001 Validation of an Mx/CAT reporter gene assay for the quantification of bovine type-I interferon. Journal of Immunological Methods 249 235-244. (https://doi.org/10.1016/S00221759(00)00359-8)

Gomez E, Sanchez-Calabuig MJ, Martin D, Carrocera S, Murillo A, Correia-Alvarez E, Herrero P, Canela N, Gutierrez-Adan A, Ulbrich S et al. 2018 In vitro cultured bovine endometrial cells recognize embryonic sex. Theriogenology 108 176-184. (https://doi.org/10.1016/j. theriogenology.2017.11.038)

Goodhand KL, Watt RG, Staines ME, Hutchinson JSM \& Broadbent PJ 1999 In vivo oocyte recovery and in vitro embryo production from bovine donors aspirated at different frequencies or following FSH treatment. Theriogenology 51 951-961. (https://doi.org/10.1016/S0093691X(99)00041-2)

Hansen TR, Sinedino LDP \& Spencer TE 2017 Paracrine and endocrine actions of interferon tau (IFNT). Reproduction 154 F45-F59. (https://doi. org/10.1530/REP-17-0315)

Hernandez-Ledezma JJ, Sikes JD, Murphy CN, Watson AJ, Schultz GA \& Roberts RM 1992 Expression of bovine trophoblast interferon in conceptuses derived by in vitro techniques. Biology of Reproduction $\mathbf{4 7}$ 374-380. (https://doi.org/10.1095/biolreprod47.3.374)

Hernandez-Ledezma JJ, Mathialagan N, Villanueva C, Sikes JD \& Roberts RM 1993 Expression of bovine trophoblast interferons by in vitro-derived blastocysts is correlated with their morphological quality and stage of development. Molecular Reproduction and Development 36 1-6. (https://doi.org/10.1002/mrd.1080360102)

Imakawa K, Tamura K, Lee RSF, Ji Y, Kogo H, Sakai S \& Christenson RK 2002 Temporal expression of type I interferon receptor in the periimplantation ovine extra-embryonic membranes: demonstration that human IFN.ALPHA. Can bind to this receptor. Endocrine Journal 49 195-205. (https://doi.org/10.1507/endocrj.49.195)

Ireland JJ, Murphee RL \& Coulson PB 1980 Accuracy of predicting stages of bovine estrous cycle by gross appearance of the corpus luteum. Journal of Dairy Science 63 155-160. (https://doi.org/10.3168/jds. S0022-0302(80)82901-8)

Jensen PL, Beck HC, Petersen TS, Stroebech L, Schmidt M, Rasmussen LM \& Hyttel P 2014 Proteomic analysis of the early bovine yolk sac fluid and cells from the day 13 ovoid and elongated preimplantation embryos. Theriogenology 82 657-667. (https://doi.org/10.1016/j. theriogenology.2014.04.028)

Johnson GA, Austin KJ, Collins AM, Murdoch WJ \& Hansen TR 1999 Endometrial ISG17 mRNA and a related mRNA are induced by interferon-tau and localized to glandular epithelial and stromal cells from pregnant cows. Endocrine 10 243-252. (https://doi.org/10.1007/ BF02738623) 
Kim MS, Min KS \& Imakawa K 2013 Regulation of interferon-stimulated gene (ISG)12, ISG15, and MX1 and MX2 by conceptus interferons (IFNTs) in bovine uterine epithelial cells. Asian-Australasian Journal of Animal Sciences 26 795-803. (https://doi.org/10.5713/ajas.2012.12529)

Kimura K, Spate LD, Green MP, Murphy CN, Seidel GE \& Roberts RM 2004a Sexual dimorphism in interferon-tau production by in vivoderived bovine embryos. Molecular Reproduction and Development 67 193-199. (https://doi.org/10.1002/mrd.10389)

Kimura K, Spate LD, Green MP \& Roberts RM 2004b Effects of oxidative stress and inhibitors of the pentose phosphate pathway on sexually dimorphic production of IFN-tau by bovine blastocysts. Molecular Reproduction and Development 68 88-95. (https://doi.org/10.1002/ mrd.20053)

Klemann SW, Li JZ, Imakawa K, Cross JC, Francis H \& Roberts RM 1990 The production, purification, and bioactivity of recombinant bovine trophoblast protein-1 (bovine trophoblast interferon). Molecular Endocrinology 4 1506-1514. (https://doi.org/10.1210/mend-4-101506)

Kubisch HM, Rasmussen TA \& Johnson KM 2003 Interferon-tau in bovine blastocysts following parthenogenetic activation of oocytes: pattern of secretion and polymorphism in expressed mRNA sequences. Molecular Reproduction and Development 64 79-85. (https://doi.org/10.1002/ mrd.10211)

Larson MA, Kimura K, Kubisch HM \& Roberts RM 2001 Sexual dimorphism among bovine embryos in their ability to make the transition to expanded blastocyst and in the expression of the signaling molecule IFN-tau. PNAS 98 9677-9682. (https://doi.org/10.1073/pnas.171305398)

Leaman D \& Roberts R 1992 Genes for the trophoblast interferons in sheep, goat, and musk ox and distribution of related genes among mammals. Journal of Interferon Research 12 1-11. (https://doi.org/10.1089/ jir.1992.12.1)

Leaman DW, Cross JC \& Roberts RM 1994 Multiple regulatory elements are required to direct trophoblast interferon gene expression in choriocarcinoma cells and trophectoderm. Molecular Endocrinology 8 456-468. (https://doi.org/10.1210/mend.8.4.8052267)

Looney CR, Lindsey BR, Gonseth CL \& Johnson DL 1994 Commercial aspects of oocyte retrieval and in-vitro fertilization (Ivf) for embryo production in problem cows. Theriogenology 41 67-72. (https://doi. org/10.1016/S0093-691X(05)80050-0)

Matsuyama S, Kojima T, Kato S \& Kimura K 2012 Relationship between quantity of IFNT estimated by IFN-stimulated gene expression in peripheral blood mononuclear cells and bovine embryonic mortality after Al or ET. Reproductive Biology and Endocrinology 10 21. (https:// doi.org/10.1186/1477-7827-10-21)

McCoski SR, Xie M, Hall EB, Mercadante PM, Spencer TE, Lonergan P \& Ealy AD 2014 Validation of an interferon stimulatory response element reporter gene assay for quantifying type I interferons. Domestic Animal Endocrinology 47 22-26. (https://doi.org/10.1016/j. domaniend.2013.12.003)

Melnick AP \& Spandorfer SD 2015 Embryo coculture: a review. Journal of Epidemiological Research 2 15. (https://doi.org/10.5430/jer. $\mathrm{v} 2 \mathrm{n} 1 \mathrm{p} 15$ )

Michael Roberts R, Liu L \& Alexenko A 1997 New and atypical families of type I interferons in mammals: comparative functions, structures, and evolutionary relationships. Progress in Nucleic Acid Research and Molecular Biology 56 287-325. (https://doi.org/10.1016/S00796603(08)61008-9)

Moll HP, Maier T, Zommer A, Lavoie T \& Brostjan C 2011 The differential activity of interferon-alpha subtypes is consistent among distinct target genes and cell types. Cytokine 53 52-59. (https://doi.org/10.1016/j. cyto.2010.09.006)

Nestorov P, Hotz HR, Liu Z \& Peters AH 2015 Dynamic expression of chromatin modifiers during developmental transitions in mouse preimplantation embryos. Scientific Reports 5 14347. (https://doi. org/10.1038/srep14347)

Paul V, Steinke K \& Meyer HH 2008 Development and validation of a sensitive enzyme immunoassay for surveillance of Cry1 $\mathrm{Ab}$ toxin in bovine blood plasma of cows fed Bt-maize (MON810). Analytica Chimica Acta 607 106-113. (https://doi.org/10.1016/j.aca.2007.11.022)
Pfaffl MW 2001 A new mathematical model for relative quantification in real-time RT-PCR. Nucleic Acids Research 29 e45. (https://doi. org/10.1093/nar/29.9.e45)

Richard C, Hue I, Gelin V, Neveux A, Campion E, Degrelle SA, Heyman Y \& Chavatte-Palmer P 2015 Transcervical collection of bovine embryos up to Day 21: an 8-year overview. Theriogenology 83 1101-1109. (https://doi.org/10.1016/j.theriogenology.2014.12.005)

Robinson RS, Fray MD, Wathes DC, Lamming GE \& Mann GE 2006 In vivo expression of interferon tau mRNA by the embryonic trophoblast and uterine concentrations of interferon tau protein during early pregnancy in the cow. Molecular Reproduction and Development 73 470-474. (https://doi.org/10.1002/mrd.20431)

Romero JJ, Antoniazzi AQ, Nett TM, Ashley RL, Webb BT, Smirnova NP, Bott RC, Bruemmer JE, Bazer FW, Anthony RV et al. 2015 Temporal release, paracrine and endocrine actions of ovine conceptus-derived interferon-tau during early pregnancy. Biology of Reproduction 93146. (https://doi.org/10.1095/biolreprod.115.132860)

Rubinstein S, Familletti PC \& Pestka S 1981 Convenient assay for interferons. Journal of Virology 37 755-758.

Sadler AJ \& Williams BR 2008 Interferon-inducible antiviral effectors. Nature Reviews Immunology 8 559-568. (https://doi.org/10.1038/ nri2314)

Shirozu T, Iwano H, Ogiso T, Suzuki T, Balboula AZ, Bai H, Kawahara M, Kimura K, Takahashi H, Rulan B et al. 2017 Estrous cycle stagedependent manner of type I interferon-stimulated genes induction in the bovine endometrium. Journal of Reproduction and Development $\mathbf{6 3}$ 211-220. (https://doi.org/10.1262/jrd.2016-176)

Spencer TE \& Bazer FW 1996 Ovine interferon tau suppresses transcription of the estrogen receptor and oxytocin receptor genes in the ovine endometrium. Endocrinology 137 1144-1147. (https://doi.org/10.1210/ endo.137.3.8603586)

Spencer TE, Stagg AG, Ott TL, Johnson GA, Ramsey WS \& Bazer FW 1999 Differential effects of intrauterine and subcutaneous administration of recombinant ovine interferon tau on the endometrium of cyclic ewes. Biology of Reproduction 61 464-470. (https://doi.org/10.1095/ biolreprod61.2.464)

Takahashi H, Takahashi M, Nagaya H, Hirako M, Sawai K, Minamihashi A, Inumaru S, Yokomizo Y, Geshi M, Okano A et al. 2005 Establishment of a specific radioimmunoassay for bovine interferon tau. Theriogenology 63 1050-1060. (https://doi.org/10.1016/j. theriogenology.2004.05.019)

Talukder AK, Rashid MB, Yousef MS, Kusama K, Shimizu T, Shimada M, Suarez SS, Imakawa K \& Miyamoto A 2018 Oviduct epithelium induces interferon-tau in bovine Day-4 embryos, which generates an antiinflammatory response in immune cells. Scientific Reports 87850. (https://doi.org/10.1038/s41598-018-26224-8)

Toji N, Shigeno S, Kizaki K, Koshi K, Matsuda H, Hashiyada Y, Imai K, Takahashi T, Ishiguro-Oonuma T \& Hashizume K 2017 Evaluation of interferon-stimulated genes in peripheral blood granulocytes as sensitive responders to bovine early conceptus signals. Veterinary Journal 229 37-44. (https://doi.org/10.1016/j.tvjl.2017.10.007)

Toji N, Koshi K, Furusawa T, Takahashi T, Ishiguro-Oonuma T, Kizaki K \& Hashizume K 2018 A cell-based interferon-tau assay with an interferonstimulated gene 15 promoter. Biomedical Research 39 13-20. (https:// doi.org/10.2220/biomedres.39.13)

Ulbrich SE, Meyer SU, Zitta K, Hiendleder S, Sinowatz F, Bauersachs S, Buttner M, Frohlich T, Arnold GJ, Reichenbach HD et al. 2011 Bovine endometrial metallopeptidases MMP14 and MMP2 and the metallopeptidase inhibitor TIMP2 participate in maternal preparation of pregnancy. Molecular and Cellular Endocrinology 332 48-57. (https:// doi.org/10.1016/j.mce.2010.09.009)

Valleh MV, Tahmoorespur M, Joupari MD, Dehghani H, Rasmussen MA, Hyttel P \& Strobech L 2015 Paternal breed effects on expression of IGFII, BAK1 and BCL2-L1 in bovine preimplantation embryos. Zygote 23 712-721. (https://doi.org/10.1017/S0967199414000367)

van der Weijden VA, Chen S, Bauersachs S, Ulbrich SE \& Schoen J 2017 Gene expression of bovine embryos developing at the air-liquid interface on oviductal epithelial cells (ALI-BOEC). Reproductive Biology and Endocrinology 15 91. (https://doi.org/10.1186/s12958-017-0310-1) 
Vejlsted M, Avery B, Schmidt M, Greve T, Alexopoulos N \& MaddoxHyttel P 2005 Ultrastructural and immunohistochemical characterization of the bovine epiblast. Biology of Reproduction 72 678-686. (https://doi. org/10.1095/biolreprod.104.034348)

Walker AM, Kimura K \& Roberts RM 2009 Expression of bovine interferontau variants according to sex and age of conceptuses. Theriogenology 72 44-53. (https://doi.org/10.1016/j.theriogenology.2009.01.017)

Wang XL, Wang K, Han GC \& Zeng SM 2013 A potential autocrine role for interferon tau in ovine trophectoderm. Reproduction in Domestic Animals 48 819-825. (https://doi.org/10.1111/rda.12169)

Yao N, Wan PC, Hao ZD, Gao FF, Yang L, Cui MS, Wu Y, Liu JH, Liu S, Chen $\mathrm{H}$ et al. 2009 Expression of interferon-tau mRNA in bovine embryos derived from different procedures. Reproduction in Domestic Animals 44 132-139. (https://doi.org/10.1111/j.1439-0531.2007.01009.x)

Received 14 June 2018

First decision 26 July 2018

Revised manuscript received 14 December 2018

Accepted 21 December 2018 